\title{
NIH gets the green light on embryo research
}

Washington. Amidst a flurry of last-minute opposition, an ad hoc panel of the National Institutes of Health (NIH) this week released a report that may pave the way for an end to a 13-year de facto ban on the federal funding of embryo research.

On Monday, a federal judge denied a request for an injunction to stop the work of the panel. The suit was brought by the International Foundation for Genetics Research, a group in Pittsburgh that funds genetics research and believes that life begins at the moment of conception.

The suit claimed that the NIH had not complied with the law in choosing the members of the panel, and that some panel members had a conflict of interest because they stood to gain research funds for embryo research. But the judge rejected the groups efforts to prevent the panel's report being presented to Harold Varmus, director of $\mathrm{NIH}$, to reject the panel's finding.

Varmus appointed the panel after Congress had overturned a regulation requiring proposals for publicly funded embryo research to be reviewed by an Ethics Advisory Board (the Reagan and Bush administrations effectively stopped all such research by not appointing anyone to this board). The panel was asked to determine what research outside the womb is acceptable on human embryos created during in vitro fertilization, and on parthenotes - eggs stimulated to develop in the absence of sperm.

Earlier this year, the new panel agreed that federal funds should in principle be spent on embryo research. It also agreed that a distinction should be made between embryos intended for transfer and those not, with the greater need for restrictions on research on the former.

In its final report, due to be published this week, the panel says that, as in Britain and Canada, research on embryos should be restricted to the first 14 days after fertilization. This is the stage at which the primitive streak appears in vivo, although because development is slower in vitro than in vivo, the panel accepts that some research could be done beyond 14 days if it is intended to identify reliably when the primitive streak appears.

The panel recommends that all embryo

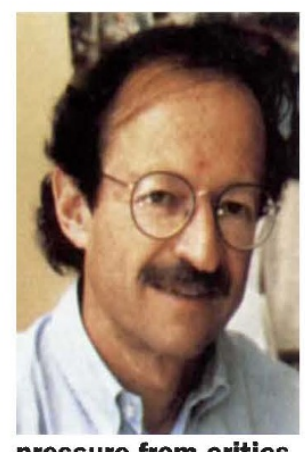
research should meet certain conditions. For example, it should be clear that the research goals cannot be met using either animals or gametes. Furthermore the experiment should be performed in the shortest possible pressure from critics time, and there should be no purchase of gametes or embryos.

Much of the panel's debate has focused on the sources of gametes and embryos, such as spares from infertility treatment, women undergoing pelvic surgery, healthy volunteers, women and girls who have died, and aborted fetuses.

The panel says that healthy women, even if volunteers, are not acceptable as donors because of the risks associated with harvesting the eggs. Those undergoing surgery or infertility treatment are acceptable, provided that there is no sale involved and informed

\section{LHC caught in French budget crunch}

Paris. The new French academic year kicked off last week with François Fillon, the French minister of research and higher education, trying to find a way out of the impasse over funding prospects for the Large Hadron Collider (LHC) being planned at the EuropeanLaboratory for Particle Physics (CERN).

Germany and the United Kingdom are demanding that France and Switzerland, as the host nations, should pay an extra 10 per cent of its costs. But France and Switzerland are not prepared to go higher than the 4.3 per cent they recently offered (see Nature 371, 187 ; 1994). "Ten per cent is out of the question," says Fillon, who says that he has written to his British and German counterparts to request a mini-summit to negotiate a settlement.

France's new austerity budget, announced in Paris last week, leaves Fillon with little room for manoeuvre. The government has virtually frozen public spending, scheduled to increase by just 1.9 per cent, in a bid to reduce its spiralling budget deficit from FFr301.4 billion (4.1 per cent of gross national product, GNP) to FFr274.6 billion by next year.

Spending on research does somewhat better than many others areas, with an increase of 3.5 per cent to FFr52.573 billion, sufficient to keep spending constant as a proportion of GNP at 2.41 per cent.

Within the budget there are few surprises. The worst news for scientists came in a separate announcement from Fillon that the freeze of 8 per cent of the research budget (excluding salaries) the government introduced in June is unlikely to be lifted, as had earlier been indicated.

One change this year is that the budget of the French space agency CNES is to be kept virtually constant, having enjoyed almost double-figure growth through the 1980 s.

Declan Butler consent has been received.

Similarly, research can be carried out an embryo from a woman or girl who has died, providing it is not intended for transfer to a uterus. But, aware of the strong emotions surrounding abortion, the panel says that it would be "unwise public policy" to allow aborted fetuses to be used as sources, irrespective of whether transfer is intended.

Judging by the letter from Congress, written by anti-abortionist Robert Dornan (Republican, California) and signed by 26 fellow congressmen, equally strong emotions are likely to surround the panel's view that research on parthenotes is acceptable providing that the activated egg is not transferred to a woman.

The panel says research on parthenotes would provide information about eggs to activate and sustain their early development, and points out that parthenotes fail to develop because they lack essential genes contributed by sperm. But Dornan says that scientists might grow stem cell lines from parthenotes to develop tissue for transplant to adults. "This creation of new life for the purpose of vivisection will be abhorrent to many Americans," the letter says.

While the list of research that it proposes should be forbidden took the panel little time to draw up, decisions on which techniques should be subject to further review were more difficult. Included in this category, for example, was research carried out on an embryo a few days after the appearance of the primitive streak, something that could aid the understanding of the large number of human diseases that arise at this time.

More contentious was the issue of whether to allow the nucleus from one woman's egg to be transplanted to another's. The panel eventually agreed to recommend that this should not be allowed if the procedure was intended either to duplicate a genome or to increase the number of embryos with the same genotype. But because the mother's mitochondrial DNA causes some inherited diseases, the panel also concluded that further review is needed of whether to allow research intended to avoid such diseases.

It is now up to Varmus to decide which of the panel's recommendations to accept. NIH expects the full guidelines to be completed by next summer and that, although they will apply only to publicly funded research, they should also serve as a model for privately funded work.

But Varmus's task will not be easy. NIH has received 18,000 letters, most expressing opposition to all research on human embryos, and individual panel members have received many hundreds more. The NIH has been sufficiently concerned to provide security guards for the protection of panel members during public meetings on the topic.

Helen Gavaghan 